\title{
Simplified model of the frequency dependence of the LFP's spatial reach
}

\author{
Szymon Łęski ${ }^{1,2 *}$, Henrik Lindén ${ }^{2,3}$, Tom Tetzlaff ${ }^{2,4}$, Klas H Pettersen², Gaute T Einevoll ${ }^{2}$ \\ From Twenty First Annual Computational Neuroscience Meeting: CNS*2012 \\ Decatur, GA, USA. 21-26 July 2012
}

One of the fundamental questions regarding the local field potential (LFP), the low-frequency part of the extracellularly recorded electric potential, is how far the signal propagates in the brain [1]. We have previously shown [2] that the low-pass filtering in dendrites [3] leads to a frequency dependent spatial spread of the LFP. These previous results were obtained by simulating a large population of morphologically reconstructed neurons. The cells were placed homogeneously within a disc of radius $R=1 \mathrm{~mm}$ (Figure 1A). We defined the reach of the LFP as a radius $r<R$ such that the cells located beyond that radius contributed no more than $5 \%$ of the total amplitude at the center of the population. We showed that the reach depends, among other factors, on the input correlation and the frequency.

Here we employ a simplified model of the population to identify the two main effects behin the frequency dependence of the reach: 1) frequency dependence of the 'transition distance', that is, the distance beyond which a single cell can be approximated as a dipole, 2) frequency dependence of the mean pairwise correlation of the single neuron contributions to the LFP. The simplified model is in agreement with the full simulation results if both effects are taken into account (Figure 1B), while neither of the factors alone is sufficient.
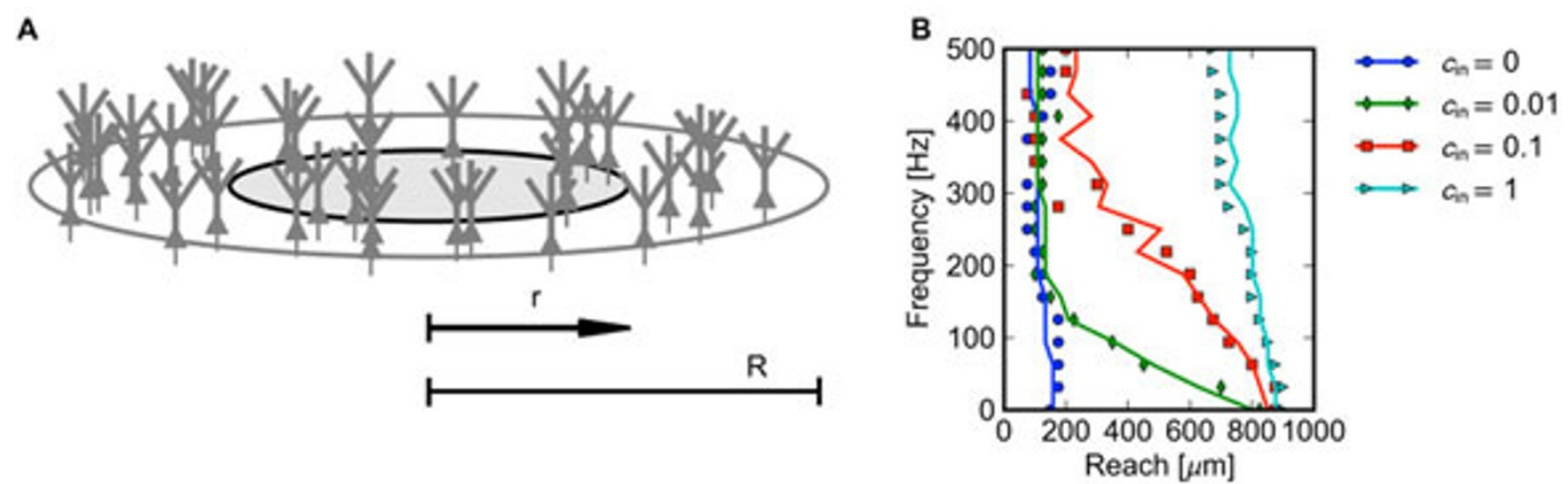

Figure 1 A. Model setup, $r$ (reach) and $R$ defined in the text. B. The reach $r$ at the soma level as a function of LFP frequency and input correlation for a population of layer 5 pyramidal neurons stimulated basally, symbols - full simulation, lines - simplified model. The input correlation is defined as a an average fraction of synaptic currents shared by each pair of neurons.

\footnotetext{
* Correspondence: s.leski@nencki.gov.pl

'Department of Neurophysiology, Nencki Institute of Experimental Biology,

Warsaw, 02-093, Poland

Full list of author information is available at the end of the article
}

\section{Ciomed Central}

(C) 2012 Łęęski et al; licensee BioMed Central Ltd. This is an Open Access article distributed under the terms of the Creative Commons Attribution License (http://creativecommons.org/licenses/by/2.0), which permits unrestricted use, distribution, and reproduction in any medium, provided the original work is properly cited. 


\section{Acknowledgements}

We acknowledge financial support from The Research Council of Norway (eVita, Yggdrasil) and the Polish Ministry of Science and Higher Education (grant N N303 542839).

\section{Author details}

'Department of Neurophysiology, Nencki Institute of Experimental Biology, Warsaw, 02-093, Poland. ${ }^{2} \mathrm{CIGENE}$, Department of Mathematical Sciences and Technology, Norwegian University of Life Sciences, Ås, 1432, Norway.

${ }^{3}$ Department of Computational Biology, School of Computer Science and Communication, Royal Institute of Technology (KTH), Stockholm, 10044 Sweden. ${ }^{4}$ Institute of Neuroscience and Medicine (INM-6), Computational and Systems Neuroscience, Research Center Jülich, 52425, Germany.

Published: 16 July 2012

\section{References}

1. Lindén H, Tetzlaff T, Potjans TC, Pettersen KH, Grün S, Diesmann M, Einevoll GT: Modeling the Spatial Range of the LFP. Neuron 2011, 72:859-872.

2. Łeski S, Lindén $H$, Tetzlaff T, Pettersen KH, Einevoll GT: Spatial reach of the local field potential is frequency dependent. BMC Neuroscience 2011, 12: P88.

3. Lindén $H$, Pettersen $\mathrm{KH}$, Einevoll GT: Intrinsic dendritic filtering gives lowpass power spectra of local field potentials. J Comput Neurosci 2010, 29:423-444.

doi:10.1186/1471-2202-13-S1-P144

Cite this article as: Łęski et al:: Simplified model of the frequency

dependence of the LFP's spatial reach. BMC Neuroscience 2012 13(Suppl 1):P144.

\section{Submit your next manuscript to BioMed Central} and take full advantage of:

- Convenient online submission

- Thorough peer review

- No space constraints or color figure charges

- Immediate publication on acceptance

- Inclusion in PubMed, CAS, Scopus and Google Scholar

- Research which is freely available for redistribution

Submit your manuscript at www.biomedcentral.com/submit 